\author{
E.R. Tazhibayeva ${ }^{1}$, T. Dolidze ${ }^{2}$ \\ ${ }^{I}$ Karagandy university of the name of academician E.A. Buketov, Kazakhstan \\ ${ }^{2}$ Batumi State Maritime Academy, Georgia \\ (Corresponding author. E-mail: mebright82@gmail.com)
}

\title{
Gains of e-collaboration in professional engagement initiatives
}

\begin{abstract}
This paper presents a single case study of SR Teaching and Learning community, initially established as an English teacher professional development company in Baku, Azerbaijan. Since July, 2020, the company has determined to enhance its geography by cooperating with academicians and practitioners from different countries by engaging official representatives from Kazakhstan, Georgia, Russia, Poland, Panama, Iran and Uzbekistan through e-collaboration processes, which aims to meet the needs of in-service and pre-service English teachers in their home countries. By investigating ongoing e-collaboration created by the community we attempted to provide a better understanding of the benefits of teachers' online collaboration and its role in teacher professional engagement initiatives. The community members' responses about the nature and extent of e-collaboration they experience served as empirical data for our study. A significant role of moderators in teaching partnership has been noted. The minority of teachers were negative about teamwork claiming that online sessions had led to increase in their personal workload.
\end{abstract}

Keywords: e-collaboration, virtual environment, technologies, e-collaborative activities, language community, in-service and pre-service teachers, professional engagement, English language.

\section{Introduction}

Currently, professional standards of teachers, which pay a greater attention to such qualities as the desire to improve professional competence, the ability to work in a team, effectively interact with colleagues, and be involved in joint projects, are being developed. The professional standard is designed to increase the motivation of teachers to work and the quality of education. Professional collaboration will allow specialists to continuously grow, develop and improve the level of their professional competence, constantly remaining relevant.

Traditionally collaboration has been regarded as one of successful strategies for teacher development. It is claimed that collegial support and sharing results plays a role in teachers' strong confidence and readiness to take risks and experiment. In this sense collaboration is a bridge between university improvement and teacher advancement. In the field of education changes are taking place that directly affect the personality of specialists.

Language teachers within remote learning are known to be instructors and moderators due to a global pandemic situation. Investigating new modes to ensure quality e-learning as a funny and engaging virtual learning environment for successful language acquisition is high on the agenda in many education institutions and communities around the world. Language teacher education programs request to address the standards of innovative education, and language experts are challenged to reconsider and reflect on their teaching traditions as well. Therefore, constant professional training for a better knowledge and skills acquisition is always welcomed [1]. In addition in every career development, collaborative working and engagement activity is "something for each individual" [2]. The success of teaching and learning practices can be found in collaboration amid fellow workers, since it enables them to refine teaching techniques and can guarantee a support and inspiration from other educators of a common passion [3]. Collaboration within a single education institution is no longer relevant in COVD-19 pandemic situation. Big gains of electronic collaboration (e-collaboration) have been argued due to its benefits of connecting a new set of educators around the globe $[4,5]$. In the nearest future the new e-collaboration systems will be developed in several dimensions, and one of them can be implemented through online collaboration processes [6].

Before elaborating on the significance of e-collaboration as a means of teacher professional development and engagement, and go deeper to the empirical data analysis, we attempted to specify the concept of e-collaboration itself. 


\section{Theoretical background}

E-collaboration encompasses a collaboration using digital technologies with other people to succeed in accomplishment of a common task [7]. E-collaboration abolishes the geographical and time obstacles and lets people from everywhere cooperate together as if side by side [8]. Traditionally, e-collaboration technologies are associated with the use of computer-mediated communication (CMM) and non-computer electronic technologies such as telephones and radio. However, virtual reality can cause the detachment of interaction from physical interlocutor co-presence to its logical extreme, and challenges the very concept of interlocutor identity. The main issue in e-collaboration perspectives with a multinational focus is to establish informal relationships to fill in academic gaps. Engagement with foreign institutions within the framework of ecollaboration ensures expert's personal development.

Kock distinguishes six major constituents of e-collaboration, including the collaborative task, the e-collaboration technologies, the individual involvement, mental schemes, and physical and social surroundings [7]. With the reference to e-collaboration between language educators a variety of activities provided in the Practical Guide are more relevant. Namely, group discussions, data collection and organization, synchronous communication, online courses and workshop participation.

Research has shown that educators who look for meeting professional needs individually fail to improve student achievements, unlike those who willingly engage in collaborative activities. For creating a quality learning environment and ensuring student progressive learning, active collaboration is of vital importance. All the activities mentioned above have their advantages for shaping teachers' professional skills in working with digital natives in the virtual environment.

For building an effective virtual environment the following technologies can be introduced to support e-collaboration (Table 1).

\section{E-collaborative activities and technologies}

\begin{tabular}{|c|c|}
\hline E-collaborative activities & Technologies to use \\
\hline Discussion groups (forums, newsgroups, conferences) & $\begin{array}{l}\text { https://voicethread.com, } \\
\text { https://padlet.com, } \\
\text { https://screencast-o-matic.com/ } \\
\text { https://jamboard.google.com/ } \\
\text { https://miro.com/ }\end{array}$ \\
\hline $\begin{array}{l}\text { Data collection, organization and sharing (curriculum resources, } \\
\text { references to articles or research papers, specific curriculum projects, } \\
\text { contact information for colleagues in relevant fields) }\end{array}$ & $\begin{array}{l}\text { http://www.curriculumresources.net/ } \\
\text { https://www.ipl.org/ } \\
\text { http://www.globalschoolnet.org/index. } \\
\text { https://classtools.net/ } \\
\text { https://www.pedagonet.com/ } \\
\text { https://www.samepage.io/ }\end{array}$ \\
\hline $\begin{array}{l}\text { Synchronous communication (online chatting, desktop video confer- } \\
\text { encing) }\end{array}$ & $\begin{array}{l}\text { http://www.chatzy.com/ } \\
\text { https://www.vidyo.com } \\
\text { https://zoom.us/ } \\
\text { https://whereby.com/ }\end{array}$ \\
\hline Online courses and workshops & $\begin{array}{l}\text { https://www.sessionlab.com/ } \\
\text { https://www.thinkific.com/ } \\
\text { https://www.learnworlds.com/ }\end{array}$ \\
\hline
\end{tabular}

Granting that online collaboration reinforces learning and sharing experience, the role of a moderator or instructor is instrumental. There are some distinctive roles for e-moderators in facilitating mediated opinion polls and discussions: pedagogical, social, managerial, and technical [9]. Pedagogically, e-moderators address questions and probe for colleagues' feedback on issues raised. Socially, e-moderators are expected to promote a constructive dialogue between participants for successful conferencing activities. Managerially, e-moderators demonstrate strong organizational, procedural, administrative skills. Technically, e-moderators 
are responsible for introducing a user-friendly technology that eliminates trouble-shooting faults until the collaborators meet their goals and objectives.

\section{Results and Discussion}

SR Teaching and Learning Language Centre is a professional educational institution that was established in 2008 in the central district of the capital city of Azerbaijan, Baku. It has been offering English courses to in-service and pre-service teachers from different countries for more than a decade. Their vision is to become the preferred language teaching organization, not only in country but also abroad. Since the birth of the company SR has invested a lot of time and effort to ensure it continues to deliver high-quality yet affordable education to language instructors from diverse backgrounds. "SR Teaching and Learning" integrates excellent and innovative approaches to language with a curriculum that incorporates culture, world languages and area studies. They also hope to offer EFL/ESL teachers the opportunities to collaborate through joint academic activities. Their programs connect a network of partners of world-known ELT leaders to bring all the aspects of teaching to life for more than 500 trainees each year. The official partners: Lexical Lab, the UK, TESOL Asia, Australia, Batumi Shota Rustaveli State University, Batumi State Maritime Academy, Teacher Professional Development Center, SUTA, Ukraine, American-Georgian School of Progress. For reinforcing teachers e-collaboration around the globe since July 2020 several representatives from the Kazakhstan, Georgia, Russia, Poland, Panama, Iran, Uzbekistan branches of the company have been appointed to create a community of English language teachers.

A qualitative research method was used to explore "SR Teaching and Learning" community members' attitudes towards e-collaboration. A qualitative research is defined as a situated activity that locates the observer in the world [10]. This study investigated an experience of a multinational e-collaboration within one language community. We focused on exploring teachers' reflections, shared individually.

Multiple sourced data was collected during the period from July 2020 to October 2020. Since the research site is the current online workplace of the researcher, it makes it a convenient and accessible site for oral and written accounts, semi-structured interviews and a survey. These accounts provided a medium to contextualize community members' activities and social roles that will constitute and explain their contribution in teachers' e-collaboration initiatives.

Seven "SR Teaching and Learning" community members were selected as subjects in the study because they participated in the most recent online events organized by the company: Evanna, Nancy, Oprah, Samanta, Charlize, Todd, and Jules (all pseudonyms). All but one members were experienced English language instructors with more than 6 years of working experience in self-funded and state endorsed institutions. Nancy has been a teacher assistant for 5 years in British School in her hometown.

Our analysis revealed that in a time period of four months the community members managed to establish friendly relationships with each other through online chatting, video-conferencing and taking an active part in online events provided by the "SR Teaching and Learning". The empirical data from online-survey showed the positive attitude and experience towards multinational e-collaboration within SR Teaching and Learning community.

The survey consisted of 12 questions with one open-ended question. Since we were interested in a welldefined variable, providing a relatively quick and easy questionnaire for the participants to complete was paramount. So the majority were designed in the close-ended pattern of a multiple choice. The survey shows that the overwhelming majority of the respondents describe themselves as highly motivated members, and only $1 / 4$ as motivated moderately. This can be explained by the teachers' personal commitment and willingness for collaborative activity by sparing one to six hours per day for it (Question 5, 6).

The pie chart illustrates in-service English language teachers' reflection on benefits of e-collaboration. Half of the survey participants strongly believe that e-collaboration is effective, since it ensures a pool for teaching and learning resources; $28,6 \%$ agreed that it provides time for reflection on teaching practices; the smallest percentage agreed that it guarantees new professional companions (figure 1). 


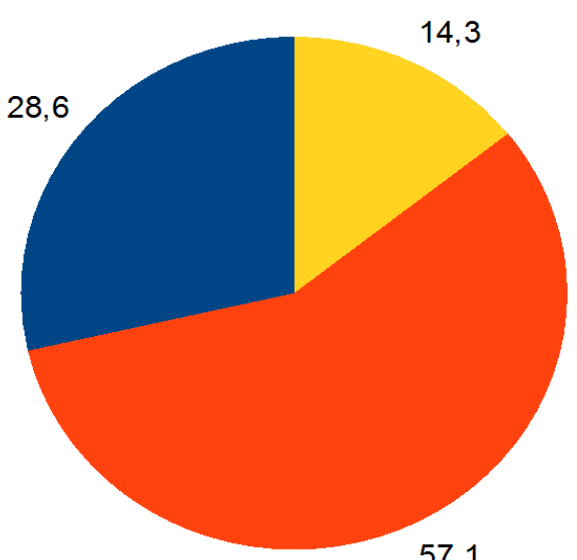

it provides time for reflection on work experiences

it provides a pool of teaching and learning resources

it provides professional companions

Figure 1. Teachers' reflection on benefits of e-collaboration

One of the challenges in collegial partnership is misinterpreted or missing information. This collaboration problem can lead to mistakes and missed deadlines which in turn can have massive consequences. The main obstacle which teachers can face in collaborating remotely is a time difference; few people suppose that poor linkages trigger difficulties, and one person believes in its inability to fully replace an offline communication (figure 2).

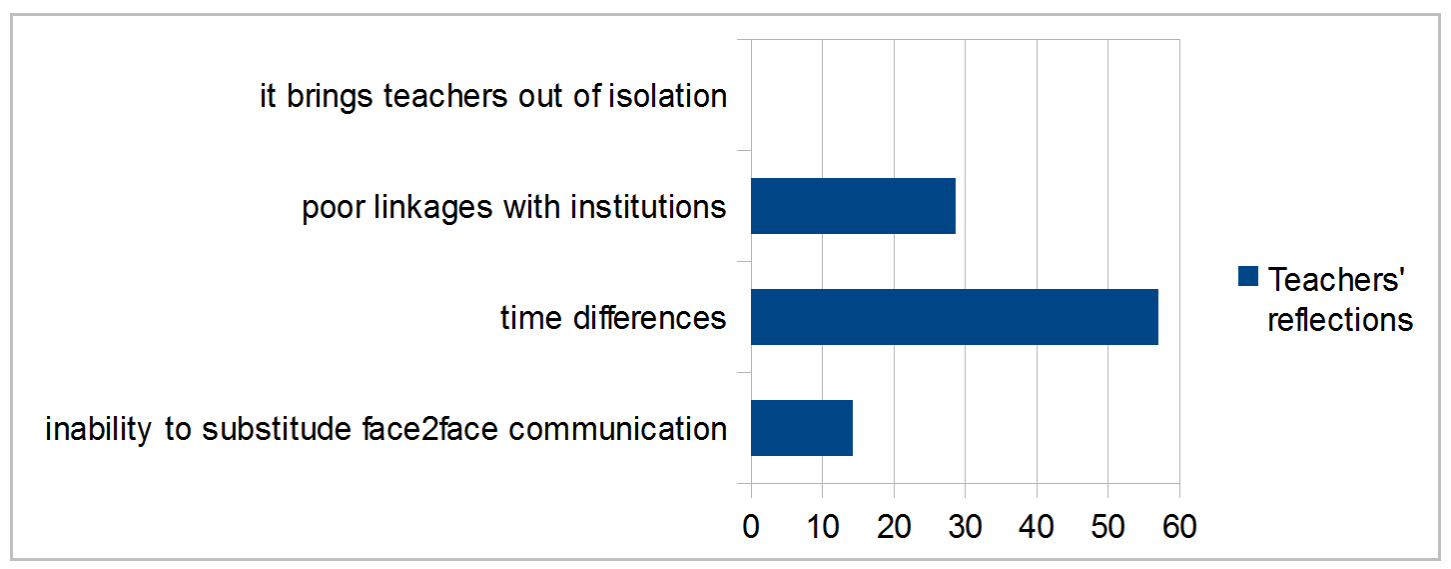

Figure 2. Teachers' reflection on obstacles

The open-ended item helped to reveal that the overwhelming majority of all respondents found Teacher's Voice Marathon and Paul Harvey training to be the most helpful input for their professional development.

Another remarkable event whitch recently took place with the active participation of community members proved how much teachers can gain from e-collaboration activities. Namely, February 15-16 "CUTOPAZLY 2021" online-conference for teachers with the help of training center "SUTO PRO" in Ukraine. A speech to Ukraini audience with the aim to reveal the features of cognitive approach to learning process at secondary schooling in Kazakhstan was delivered. The report has presented information about the academic policy and international bachelor program at Nazarbayev Intellectual School located in Nur-Sultan. The participants of the conference could gain a lot of facts and figures about some features of students' activities in classroom and out of the classroom within IB Learner profile. The majority of active listeners showed interest in CAS (C-creativity, A-activity, S-service), a long term project for high school students, which is aimed at developing creative skills, advocating healthy life style and being a socially active member of the community. That was a great opportunity to reveal best practices of national schooling system for neighboring countries and for exchanging ideas within online conference by a full engagement in e-collaboration.

For locating another credible research participants online we referred to the generated sample frame. Since this method is effective to identify people who are willing to consider taking part in the study, we were seeking their permission to contact them privately to discuss the issue in detail [11]. Using text messaging through a mobile device and video conferencing, participants we were asked to ponder over the further per- 
spectives of e-collaboration. All the participants emphasized the importance of teachers' sharing and caring practices through the e-collaborative activities. The language experts recognized peer dialogue as a source for learning and professional development. Likewise, one of the participants stressed her reconsidering the potentials and perspectives of working together with people from different cultural backgrounds and geographically dispersed areas: "Individuals at each end rely on the peer support, admitting the fact that technological scarcity delays completion of multinational collaborative tasks. We should look for better ideas in cooperating globally by getting more involved in joint publications and peer teachers projects to ensure teacher professional engagement".

\section{Conclusion}

In today's world successful implementation of e-collaboration between language instructors is a must. The study of electronic collaboration is relatively new, but globalization predicts greater popularity of ecollaboration practices in the academic environment. Through close examination of the SR Teaching and Learning community experience and its members' collaboration activities we can conclude that teachers gain much from the meaningful online discussions. There is a high degree of agreement about the successful strategies and principles in the area of teachers' e-collaboration. One also can not neglect the role of moderators in establishing better academic relationships, in choosing appropriate technologies for teachers ' professional engagement, defining clear roles and expectations, regular ongoing instructor presence.

In the article we provided operational definition of e-collaboration, discussed key elements of teacher collaboration, the functions of moderators in cooperating initiatives, provided the case study aimed at checking the efficiency of teachers' e-collaboration within a multinational community. As advancement for language teacher development it is less time and cost consuming, therefore it raises its efficiency and relevance, prepares teachers for lifelong learning. One should take into consideration three parts of a project:

- organizational culture;

- scrupulous and detailed plan;

- technology.

Because there are not many e-collaboration products on the market that provide complete answer to teacher and language community needs, there is a great potential in creating domestic implementations.

\section{References}

1 Jack C. Richards, Thomas S.C. Farrell. (2005). Professional Development for Language Teachers. Strategies for Teacher Learning. Cambridge University Press. P. 200.

2 Julie Reeves, Sue Starbuck, Alison Yeung, Inspiring collaboration and engagement. SAGE publications, Ltd.

3 Ann Koufman-Frederick, Martha Lillie, Laurie Pattison-Gordon, Daniel Lynn Watt, Richard Carter. (1999). Electronic Collaboration: A Practical Guide for Educators. LAB at Brown University.

4 Marie-Noëlle Bessagnet, Lee Schlenker, \& Robert Aiken. (2005). Using e-collaboration to improve management education: three scenarios. JISTEM Journal of Information Systems Technological Management (Online), Vol. 2, No. 1, São Paulo, P.81-94. https://doi.org/10.1590/S1807-17752005000100007//

5 Christos Bouras, Eri Giannaka, \& Thrasyvoulos Tsiatsos. (2008). E-Collaboration Concepts, Systems and Applications. researchgate.net. Retrieved from https://www.researchgate.net/publication/228641526

6 Through Growth to Achievement: Report of the Review to Achieve Educational Excellence in Australian Schools. (2018). files.eric.ed.gov. Retrieved from https://files.eric.ed.gov/fulltext/ED586130.pdf

7 Kock, N., \& D'Arcy, J. (2001). Resolving e-collaboration paradox. The competing influences of media naturalness and compensatory adaptation. Information management and consulting (Special issue on electronic collaboration), 7/4, 74-78.

8 Marie-Noëlle Bessagnet, Lee Schlenker. (2005). Using e-collaboration to importe management edukation: Three scenarios. Journal of Information Systems and Technology Management, 81-94.

9 Berge, Z.L. (1995). Facilitating Computer Conferencing: Recommendations From the Field. Educational Technology, 35(1). 22-30. berge@umbc.edu

10 Norman, K. Denzin, Yvonna S. Lincoln, (2008). The landscape of qualitative research. Sage Publications, Inc.

11 Ritchie, J. \& Lewis, J. (2003). Qualitative Research Practice: A Guide for Social Science Students and Researchers. Sage Publications, London. 


\title{
Э.Р. Тажибаева, Т. Долидзе
}

\section{Кәсіби қатысушылықты бастаудағы электронды ынтымақтастықтың артықшылықтары}

\begin{abstract}
Мақалада бастапқыда Бакуде (Әзірбайжан) ағылшын тілі мұғалімдердің кәсіби біліктерін жоғарлатуымен айналысатын компания ретінде құрылған SR Teaching and Learning білім беру қауымдастығының бірегей тәжірибесі ұсынылған. 2020 жылдың шілдесінен компания Қазақстан, Грузия, Ресей, Польша, Панама, Иран, Өзбекстанның ресми өкілдерін тарта отырып, түрлі елдердің академиктері мен тәжірибешілерімен ынтымақтасып, жағрафиясын кеңейтуге шешім қабылдады. Электрондық ынтымақтастық процестері әр елдегі ағылшын тілі мұғалімдері мен болашақ ұстаздардың қажеттіліктерін қамтамасыз етуге бағытталған. Қауымдастықтың нәтижесінде пайда болған электронды ынтымақтастықты зерттеуде авторлар мұғалімдердің онлайн-ынтымақтастығының артықшылықтары және оның мұғалімдерді кәсіби тарту бастамаларындағы рөлін жақсы түсінуге тырысқан. Қауымдастық мүшелерінің электронды ынтымақтастықтың сипаты мен ауқымы туралы жауаптары зерттеудің эмпирикалық материалына негіз болды. Онлайн-ынтымақтастықта модераторлардың ерекше рөлі атап өтілді. Зерттеуге қатысушылардың аз бөлігі онлайн кездесулер олардың жұмыс жүктемесінің артуына әкелді деп мәлімдеп, мұндай біріккен шараларға жағымсыз пікірлер білдірді.
\end{abstract}

Кілm сөздер: электрондық ынтымақтастық, виртуалды орта, технологиялар, электронды ынтымақтастықтағы іс-әрекеттер, тілдік қоғамдастық, мұғалімдер мен болашақ мұғалімдер, кәсіби тарту, ағылшын тілі.

\section{Э.Р. Тажибаева, Т. Долидзе \\ Преимущества электронного соотрудничества в инициировании профессиональной вовлеченности}

В статье представлен единичный опыт образовательного сообщества SR Teaching and Learning, первоначально созданного как компания, деятельность которой направлена на профессиональное развитие учителей английского языка в Баку (Азербайджан). С июля 2020 г. компания решила расширить свою географию, сотрудничая с академиками и практиками из разных стран, привлекая официальных представителей из Казахстана, Грузии, России, Польши, Панамы, Ирана и Узбекистана посредством реализации электронного сотрудничества, направленного на удовлетворение потребностей учителей и будущих учителей иностранного языка в своих странах. Исследуя текущее электронное сотрудничество, созданное сообществом, авторы статьи предприняли попытку понять преимущества онлайн сотрудничества учителей и его роль в инициативах по профессиональному вовлечению учителей. Отзыв членов сообщества о характере и масштабах электронного сотрудничества, с которыми они столкнулись, послужил эмпирическим материалом для исследования. Ими оотмечена значительная роль модераторов в коллоборации учителей. Меньшая часть участников исследования отрицательно выразились относительно электоронного соотрудничества, утверждая, что онлайн встречи привели к увеличению их собственной рабочей нагрузки.

Ключевые слова: электронное сотрудничество, виртуальная среда, технологии, электронная совместная деятельность, языковое сообщество, практикующие учителя, будущие учителя, профессиональная вовлеченность, английский язык. 